\title{
En mann i 60-årene med alvorlig hypotensjon og ødemer
}

\author{
En mann ble innlagt med synkope og hypotensjon etter å ha følt seg \\ slapp i noen dager. Han hadde et uvanlig stort væskebehov, økende \\ $\varnothing$ demer og utviklet en livstruende tilstand. Diagnosen som ble satt \\ under oppholdet representerer en svært sjelden tilstand.
}

En mann i 60-årene ble innlagt på sykehus en sen kveld etter å ha besvimt på badet. Han hadde følt seg tiltakende slapp de siste dagene før innleggelsen, men ellers ikke merket noe spesielt. Han var de siste 10-12 årene blitt behandlet for hypertensjon, initialt med amlodipin (Norvasc), senere carvediol, irbesartan/hydroklortiazid (CoAprovel) og moksonidin (Physiotens). I tillegg brukte han Albyl-E $75 \mathrm{mg} \times 1$. Han var ellers i god fysisk form foruten sekvele $i$ form av bilateral droppfot etter tidligere alvorlig iskemi i underekstremitetene.

I akuttmottaket hadde han forbigående bradykardi og blodtrykksfall. Det laveste blodtrykket ble målt til 64/27. Han var samtidig slapp, klam og blek. Etter infusjon av intravenøs væske ( $\mathrm{NaCl} 0,9 \%)$, kom han seg og var $i$ såpass god form at han ble lagt på vanlig sengepost. Pulsen var på 70, blodtrykket $109 / 64$ og temperaturen $37,9^{\circ} \mathrm{C}$. Han var hele tiden våken og klar, og undersøkelsen ved innkomst var ellers uten anmerkning.

Ulike årsaker til synkope ble vurdert. Med normale EKG-funn, ingen brystsmerter eller tungpust, og tørr og varm hud mellom blodtrykksfallene var det lite sannsynlig med akutt kardial eller vaskulær årsak til synkope. Han ble likevel overvåket med telemetri for eventuell arytmi. Årsaken kunne være en vasovagal utløst synkope i forbindelse med toalettbesøk eller en noe høy dose med blodtrykksmedikamenter. På grunn av den lette temperaturstigningen vurderte vi også muligheten for en begynnende infeksjon, men vi avventet oppstart av behandling til han var observert noe lenger.

Noen timer etter innkomst fikk pasienten på nytt blodtrykksfall ved stillingsendring. Han var igjen kaldsvett og uvel og ble overflyttet til intensivavdeling. Systolisk blodtrykk var rundt $70 \mathrm{~mm} \mathrm{Hg}$, og urinproduksjonen var minimal. Vi fortsatte derfor å gi væske og startet pressorbehandling i form av noradrenalin.

Utover dag 2 vedvarte det lave blodtrykket, og situasjonen var fortsatt uavklart. Vi valgte derfor å starte bredspektret antibiotika (meropenem og tillegg av erytromycin i starten), dette selv om CRP ca. 14 timer etter innleggelsen kun var 6 og det ikke var temperaturstigning.

Ekkokardiografi samme dag viste en liten hypertrof venstre ventrikkel med god kontraktilitet og funn som tydet på betydelig hypovolemi. I løpet av dag 2 ble det gitt totalt 23 liter væske intravenøst, derav 14000 ml Ringeracetat, $7000 \mathrm{ml}$ 0,9\% NaCl og $2000 \mathrm{ml}$ Glukacel $10 \%$. Det systoliske blodtrykket svingte fortsatt mellom $70 \mathrm{~mm} \mathrm{Hg}$ og $100 \mathrm{~mm} \mathrm{Hg}$ lgjennomsnittlig arterielt trykk (MAP) var $50-80 \mathrm{~mm} \mathrm{Hg}$ ), til tross for væskemengden og to pressorer (maksimal dose noradrenalin $0,5 \mu \mathrm{g} / \mathrm{kg} / \mathrm{min}$ og dopamin $8 \mu \mathrm{g} / \mathrm{kg} / \mathrm{min}$, som etter hvert ble skiftet til dobutamin $10 \mu \mathrm{g} / \mathrm{kg} /$ min). Hemoglobinverdien var ved innkomst 20,3 g/dl(13,4-17,0 g/dl). Selv om det var gitt mye intravenøs væske, hadde hemoglobinverdien steget til 23,1 g/dl dag 2, med erytrocyttvolumfraksjon/hematokrit målt til 0,67 l/l (0,39-0,50). I tillegg viste blodprøver fallende albuminverdier, og det var en økende hyperkloremisk metabolsk acidose. Tabell 1 viser laboratorieverdiene. Han hadde økende generelle ødemer, og til tross for rikelig væske hadde han minimal urinproduksjon $(750 \mathrm{ml}$ døgn som falt til $112 \mathrm{ml} /$ døgn det tredje døgnet).

Dag 2 ble det gjennomført venesectio med tapping av rundt $300 \mathrm{ml}$ blod som forsøk på å motvirke hemokonsentrasjonen. Siden det var høy tromboserisiko, ble det i tillegg gitt enoksaparin (Klexane) $40 \mathrm{mg}$ som tromboseprofylakse i starten. Etter hvert falt hemoglobinverdiene, det var lave trombocyttall og forstyrrelser i koagulasjonssystemet som viste seg $\mathrm{i}$ form av fallende fibrinogen og stigende aktivert partiell tromboplastintid (APTT) og INR-verdi. D-dimer var hele tiden normal, i motsetning til det man kunne forvente ved en eventuell disseminert intravaskulær koagulasjon (DIC). Pasientens tilstand var ustabil med oligo/anuri, ødemer, hypotensjon, høye kloridverdier samt metabolsk acidose med $\mathrm{pH}$-verdi 7,17 (referanse

\author{
Margaret Garnes \\ margaret.garnes@helse-mr.no \\ Medisinsk avdeling \\ Jens Bøen \\ Avdeling for anestesi \\ Ålesund sjukehus \\ Helse Møre og Romsdal
}

Engelsk oversettelse på www.tidsskriftet.no 
Tabell 1 Oversikt over noen utvalgte blodprøver tatt under oppholdet. Der det er anført flere svar, er det tatt flere prøver i løpet av dagen

\begin{tabular}{|c|c|c|c|c|c|c|}
\hline & Dag 1 & Dag 2 & Dag 3 & $\operatorname{Dag} 4$ & Dag 5 & Dag 6 \\
\hline Hemoglobin, g/100 ml (ref. 13,4-17,0) & 20,3 & $20,9-23,1-19,0$ & $12,6-9,3$ & $11,3-8,2$ & 9,6 & 9,4 \\
\hline Trombocytter, 10\%/l (ref. 145-390) & 229 & 281 & $110-43$ & $56-37$ & $39-30$ & 44 \\
\hline Albumin, g/l ref. $36-45$ & 26 & 17 & $<10-14$ & 15 & 16 & 18 \\
\hline C-reaktivt protein, mg/l (ref. 0-6) & 5 & 6 & 24 & 67 & 71 & 58 \\
\hline Kreatinkinase, U/L (ref. 0-280) & 51 & 45 & - & 33309 & 30743 & - \\
\hline Protrombintid- INR (ref. 0,8-1,2) & 1,4 & 1,5 & $3,9-1,5$ & 1,2 & 1,2 & 1,0 \\
\hline D-dimer, mg/l (ref. 0,0-0,4) & - & - & 0,2 & - & - & - \\
\hline Kreatinin, $\mu \mathrm{mol} / \mathrm{l}$ (ref. 60-100) & 133 & 171 & 146 & 121 & 120 & 117 \\
\hline Laktat, mmol/l (ref. 0,7-2,1) & - & $1,3-5,1$ & $4,8-3,2$ & $2,9-2,1$ & - & 1,2 \\
\hline
\end{tabular}

7,37-7,44), baseoverskudd $-12,3 \mathrm{mmol} / 1$ (referanse $-2,4-2,3 \mathrm{mmol} / \mathrm{l}$ ) og laktat 2,6 $\mathrm{mmol} / \mathrm{l}$ (referanse $0,7-2,1 \mathrm{mmol} / \mathrm{l})$. På ettermiddagen dag 2 startet vi derfor med kontinuerlig venovenøs hemodiafiltrasjon (CVVHDF). Sitrat ble brukt som antikoagulant.

Til tross for oppstart av kontinuerlig venovenøs hemodiafiltrasjon viste arterielle blodgasser på nytt forverring av acidose. Han hadde økende respiratorisk besvær, trolig som følge av økende lekkasje av væske også i alveolene, og han var vedvarende hemodynamisk ustabil. Han ble derfor intubert og lagt på respirator om natten ca. 30 timer etter at han ble innlagt. Arteriell blodgass i forkant av intubasjonen viste $\mathrm{pH} 7,06, \mathrm{BE}-18,3 \mathrm{mmol} / \mathrm{l}$ og laktat 5,1 mmol/l. Han var da også svært kald perifert, hadde blåmarmorert hud, økende smerter $i$ armer og bein og behovfor opiater. Ortopedene fulgte ham tett med tanke på høyt muskeltrykk og eventuelt behov for fasciotomi.

Normalt trykk i musklenes interstitielle rom er rundt $2-8 \mathrm{~mm} \mathrm{Hg}$. Ofte er trykk rundt 30 $\mathrm{mm} \mathrm{Hg}$ satt som en indikasjonsgrense for fasciotomi, men lavere trykk kan også i visse situasjoner indikere høy risiko for iskemi og nevromuskulære skader og dermed gi behov for fasciotomi. Før fasciotomi vurderes i tillegg til trykk også andre parametere som blant annet økende smerter, perfusjon og pasientens generelle tilstand. Det ble derfor besluttet å gjennomføre fasciotomier etter intubasjon. Da var trykket $60 \mathrm{~mm} \mathrm{Hg}$ i dorsale kompartment i venstre underarm, 40 $\mathrm{mm} \mathrm{Hg}$ i høyre underarm dorsalt og omtrent 30 mm Hg i legger og lår.

Noen timer etter intubasjonen ble det i morgentimene dag 3 gjennomført fasciotomi på alle ekstremiteter (legger, lår, underarmer).
Pasienten var i disse timene sirkulatorisk svært ustabil og hadde i etterkant av operasjonen relativt rikelig med blødninger fra begge underarmer. Etter noen timer ble det besluttet å reoperere han på en intensivstue. Det var da mange små diffuse blødninger som ble stoppet med diatermi. Nå så man forstyrrelser i koagulasjonsprøvene, med mellom annet betydelig stigning i INR, lav fibrinogen og høy APTT, og han hadde økt blødningstendens. Det ble derfor i løpet av de neste to døgn gitt 16 enheter plasma, 11 enheter erytrocyttkonsentrat (SAG) og to enheter trombocytter.

Ved en innleggelse noen år tidligere var det sett et liknende klinisk bilde. Den gangen førte hemokonsentrasjonen til at han utviklet alvorlig iskemi i legg- og lårmuskulatur. Muskellosjetrykket var høyt og han hadde behov for fasciotomi. Ved angiografi ble det påvist trombose i arteria femoralis samt okkludert a. tibialis anterior og a. fibularis på venstre side. Det ble gjennomført hyperbar oksygenbehandling og trombendarterektomi ved et universitetssykehus. Han unngikk amputasjon, men han utviklet sekvele i form av droppfot bilateralt og hadde behov for skinner. Etter den akutte episoden hadde han også vedvarende kolikkpregede magesmerter og det ble påvist skadet tarm som følge av tidligere iskemi. Et halvt år etter oppholdet ble det derfor gjennomført tarmreseksjon og adheranseløsning.

$\mathrm{Vi}$ vurderte forskjellige former for angioødem som mulig årsak til den alvorlige kapillærlekkasjen. Pasienten hadde ingen familieanamnese eller ødemer spesielt i hals/ansikt som en ser ved hereditært angioødem. Det var derfor liten klinisk mistanke om denne tilstanden. I det akutte forløpet valgte vi å gi icatibant (Firazyr) for å dempe eventuell bradykinindrevet kapillærlekkasje. Dette ble gitt som ferdigfylte $30 \mathrm{mg}$ sprøyter subkutant i tre doser med seks timers mellomrom i løpet av dag 3 .

I etterkant av det akutte forløpet fikk vi prøvesvar som viste at $\mathrm{C} 1$-inhibitorkvantiteringen var lav, mens C1-inhibitorfunksjonstest var normal. De lave verdiene ble normalisert etter at pasienten var restituert. Dette passer med et generelt proteintap under kapillærlekkasjen og ikke med hereditært angioødem.

Etter tilkobling til kontinuerlig venovenøs hemodiafiltrasjon ble han også hemodynamisk overvåket ved PiCCO (Pulse Contour Cardiac Output Monitoring). Han hadde fra målingene startet om natten til dag 3 svært lav kardial indeks (C) på 1,6-1,7 l/min/ $/ \mathrm{m}^{2}$ (referanse 3,0-5,0 l/min/m²). På dag 3 hadde han slagvolumvariasjoner på 11-29\% (normal slagvolumvariasjonsgrense (SVV) er under $10 \%$, og ved hypovolemi ofte over $20 \%$ ). Etter fasciotomiene hadde han utover dag 3 fortsatt lav kardial indeks, men han fikk en normalisering av perifer motstand. Denne hadde preoperativt vært ekstremt høy og ble tolket som en konsekvens av et losjesyndrom. Etter hvert som slagvolumvariasjonen gikk ned mot normale verdier på under og rundt $10 \%$, gikk kardial indeks opp mot normale verdier på > 3,0 $\mathrm{l} / \mathrm{min} / \mathrm{m}^{2}$. Dette skjedde først på kvelden dag 3/natt til dag 4.

En rekke kliniske tilstander er ledsaget av hypotensjon og ødemer. Differensialdiagnoser kan derfor være alvorlig sepsis, septisk sjokk, toksisk sjokksyndrom, anafylaksi eller medikamentreaksjoner samt eventuelt hereditært angioødem. Andre diagnoser som kan vurderes ved dette kliniske bildet er polycythaemia vera, binyrebarksvikt, Gleichs syndrom (episodisk angioødem og eosinofili), mastcellesykdom, karsinoid syndrom, primær amyloidose og uttalt hjertesvikt. 
Den betydelige kapillærlekkasjen ble diskutert på morgenmøtet på medisinsk avdeling dagen etter at pasienten ble innlagt. Vi gjorde et litteratursøk på kapillærlekkasje, og diagnosen idiopatisk systemisk kapillærlekkasjesyndrom (idiopathic systemic capillary leak syndrome, ISCLS) kom opp. Diagnosen viste seg å kunne passe med funnene og pasientens sammensatte og alvorlige sykehistorie.

Underveis i det akutte forløpet ble det konferert med universitetssykehus flere ganger. Han fikk som følge av anbefalinger kortikosteroider intravenøst (Solu-Cortef) $100 \mathrm{mg} \times 4$, samt fra dag 2 også gammaglobuliner intravenøst (Kiovig) $0,4 \mathrm{~g} / \mathrm{kg}$ kroppsvekt i fem dager. Overflytting ble også diskutert, men siden de viktigste tiltakene $\mathrm{i}$ den kritiske situasjonen var ivaretatt, ble ikke det gjennomført.

Under forløpet ble det gjennomført en rekke undersøkelser for å finne en eventuell bakenforliggende årsak til tilstanden. Det ble tatt utvidede blodprøver og diverse undersøkelser med tanke på virus og bakterier (cytomegalovirus, Epstein-Barr-virus, $\mathrm{Myco}$ plasma, Chlamydia, Hemophilus influenzae, influensa A og B), immunologiske undersøkelser (antinukleære antistoffer og antinøytrofile cytoplasmiske antistoffer), og diverse andre prøver (s-kortisol, fritt tyroksin /thyreoideastimulerende hormon, prokalsitonin, senkningsreaksjon, kuldeagglutininer, s-proteinelektroforese, $\mathrm{C} 1$-inhibitor, komplementfaktorene $\mathrm{C} 3$ og $\mathrm{C} 4$, haptoglobin $\mathrm{mfl}$.). Ingen av disse viste noe som var av sikker betydning for tilstanden.

Utover dag 4 syntes pasienten å være mindre pressorkrevende og trenge mindre væske, og blodtrykket bedret seg. Ved innkomst var pasientens vekt rundt $100 \mathrm{~kg}$, mens den på dag 5 ble målt til $130 \mathrm{~kg}$. Han hadde da et betydelig ekstravasalt væskeoverskudd, og i løpet av de neste dagene ble det blant annet gjennomført pleuratappinger bilateralt. Etter hvert fikk han økt diurese, og kontinuerlig venovenøs hemodiafiltrasjon ble avsluttet dag 9. Han ble ekstubert dag 10 og utskrevet etter omtrent en måned på sykehus.

Etter dette siste sykehusoppholdet har pasienten hatt vedvarende ryggsmerter, og han har fått påvist betydelige degenerative ryggforandringer og muskelskade/muskelfibrose. Dette er trolig delvis utløst av hypoperfusjon og iskemisk skade under anfallet. Pasienten følges med regelmessige kontroller ved medisinsk poliklinikk. Han har altså hatt anfall av idiopatisk systemisk kapillærlekkasjesyndrom med 4-6 års mellomrom, og det er nå noen år siden siste anfall. Pasienten får forebyggende behandling med terbutalin (Bricanyl) og teofyllintabletter, i tillegg til behandling for hypertensjon.

\section{Diskusjon}

Idiopatisk systemisk kapillærlekkasjesyndrom er en sjelden tilstand som er karakterisert av uttalt hypotensjon, hypoalbuminemi og hemokonsentrasjon. Den ble første gang beskrevet av Clarkson i 1960 og er derfor også kjent som Clarksons syndrom (1). Det er kun ca. 150 tilfeller rapportert i verden. Typisk rammes middelaldrende voksne, selv om enkelttilfeller hos barn ned til fem måneders alder er blitt rapportert (2).

For å sette diagnosen trengs det ett eller flere anfall som møter følgende kriterier (3): - ødem med mer enn $1 \mathrm{~kg}$ akutt vektøkning $(<$ en uke)

- akutt hypotensjon med systolisk blodtrykk $<100 \mathrm{~mm} \mathrm{Hg}$ eller gjennomsnittstrykk $<70 \mathrm{~mm} \mathrm{Hg}$

- hemokonsentrasjon (økning i hematokrit eller hemoglobin over normalverdi for alder og kjønn med mer enn $20 \%$ av siste referanseverdi for pasienten), med hypoproteinemi eller hypoalbuminemi

- at andre årsaker til kapillær lekkasje eller hypoproteinemi er ekskludert

At det var et akutt anfall med idiopatisk systemisk kapillærlekkasjesyndrom, ville også kunne forklare mannens alvorlige tilstand noen år tidligere. I tillegg kunne et opphold rundt ti år tidligere passe inn i denne sammenhengen. Da hadde han vært innlagt med forbigående forhøyet hemoglobin på $19,8 \mathrm{~g} / \mathrm{dl}$ og stigning i kreatinin. Man gjennomførte da venesectio med tapping av $600 \mathrm{ml}$ blod. Blodverdiene normaliserte seg raskt og utredningen ga ingen sikre funn.

Hva som ligger bak og forårsaker anfallsvis hyperpermeabilitet ved idiopatisk systemisk kapillærlekkasjesyndrom, er fortsatt ikke kjent. Det har vært fremsatt forskjellige hypoteser, for eksempel forbigående endoteldysfunksjon via apoptose (4) eller mulig sammentrekning av endotelcellen (5).

I den seneste debatten rundt patogenesen har man diskutert modeller der ikke-immunglobuline humorale faktorer kan bidra til forbigående sammentrekking av endotel (for eksempel vaskulær endotelial vekstfaktor og angiopoietin-2) (5). Ca. $80 \%$ av pasientene med idiopatisk systemisk kapillærlekkasjesyndrom har monoklonal gammopati av usikker signifikans $(3,4)$, slik vår pasient har. Men det er fortsatt usikkert om dette patologiske immunglobulinet har klinisk betydning eller kun er et tilfeldig funn (2)

Det er vist at vaskulær endotelbarrierefunksjon er opprettholdt av intercellulære kontakter hovedsakelig gjennom vaskulær endotelial cadherin (VE-cadherin). Teofyllin (fosfodiesterasehemmer) og terbutalin ( $\beta$-adrenerg agonist) (6) er utenom intravenøs immunglobulin (7) eneste behandling som er vist å kunne redusere antall og alvor- lighetsgrad av anfallene. Teofyllin og terbutalin fremmer endotelbarrierefunksjon gjennom å stabilisere VE-cadherinmediert adhesjonsjunksjon (adhesive junctions), og de antas også å øke innhold av intracellulær syklisk adenosinmonofosfat (cAMP) som motvirker kapillær lekkasje. Tidligere har man ment at bruken av beta-2-agonister fører til reduksjon av kapillærpermeabilitet indusert ved histamin og bradykinin, men disse inflammasjonsmediatorene har muligens mindre betydning ved idiopatisk systemisk kapillærlekkasjesyndrom (5).

Per i dag er det ingen etablert behandling for anfallene. Hos noen få pasienter er det blitt beskrevet vellykket akutt behandling med høye doser intravenøs immunglobulin (7). Anfallene kan komme én gang i livet, mens andre kan ha mange anfall $i$ året. Kliniske symptomer kan deles inn i tre faser. I den første prodromalfasen har ca. $30 \%$ en øvre luftveisinfeksjon. Ca. $50 \%$ har mer diffuse symptomer de siste to dagene før det akutte anfallet, slik som slapphet, irritabilitet, magesmerter, kvalme, myalgi, diaré, tørste, feber og rask vektøkning.

Den akutte fasen med betydelig kapillærlekkasje varer 1-3 døgn. (2) Da får pasienten en kombinasjon av hypotensjon, hemokonsentrasjon, eventuelt leukocytose og trombocytose og hypoalbuminemi (albumin oftest $<20 \mathrm{~g} / \mathrm{dl}$ (4)). Proteiner med molekylvekt $\leq 200$ kilodalton, som albumin, lekker fra det intravaskulære til det interstitielle rommet. Det er derfor ofte et generalisert ødem, med mulighet for acites, pleuravæske, perikardeffusjon, cerebralt ødem og encefalopati. Losjesyndrom kan oppstå, som igjen kan føre til rabdomyolyse og nyresvikt. Grad av albumintap korrelerer med risiko for utvikling av rabdomyolyse (4). Den lave perfusjonen vil som oftest medføre akutt tubulær nekrose og ofte iskemisk hjerneskade og/eller iskemisk hepatitt.

Etter noen dager stopper kapillærlekkasjen og den tredje fasen, restitusjonsfasen, starter. Overgangen kan skje raskt og er karakterisert ved en nedgang i mengden intravenøs væske som trengs for å opprettholde det intravaskulære volumet. Pasienten har i denne fasen høy risiko for overvæsking og lungeødem (2).

Dødeligheten ved akutte anfall med idiopatisk systemisk kapillærlekkasjesyndrom er ukjent. I to artikler med henholdsvis 25 (4) og 28 (3) pasienter ble det funnet en femårsoverlevelse på $76 \%$ og $73 \%$. I sistnevnte pasientserie var femårsoverlevelsen $85 \%$ hos 23 pasienter som hadde fått profylaktisk behandling, og $20 \%$ hos fem pasienter som ikke fikk forebyggende behandling (3). Det var benyttet forskjellige medikamenter i den profylaktiske behandlingen, blant annet terbutalin, teofyllin og immunglobuliner. Dødsårsaken er ofte lungeødem i rekonvalesens- 
fasen eller iskemisk organsvikt som følge av hypoperfusjon i akuttfasen.

Man diskuterer om det også finnes sekundære former for idiopatisk systemisk kapillærlekkasjesyndrom. Dette skyldes at det er rapportert om liknende tilstander der man kjenner den sannsynlig utløsende faktoren, f.eks. medikamenter som granulocyttkolonistimulerende faktor (8), interferon (9), gemcitabin (10) og sirolimus (11).

Vi har behandlet en kritisk syk pasient med en svært sjelden tilstand. Diagnostikken var vanskelig og diagnosen måtte i stor grad baseres på eksklusjoner. Det finnes heller ingen etablert behandling. Inflammasjonsdrevet kapillærlekkasje med bl.a. bradykinin som bidragende faktor er ut ifra en av de siste artiklene om temaet (5) mindre sannsynlig. Det er derfor usikkert om høye doser steroider og bradykinin type 2-reseptorantagonister (Firazyr) bidro positivt. Hva som er den rette støttende behandlingen kan også diskuteres. Kunne mer bruk av Ringer-acetat som intravenøs væske heller enn $\mathrm{NaCl} 0,9 \%$ ha bidratt til mindre uttalt hyperkloremisk acidose? Kunne en begrenset tilførsel av væske og større forbruk av kolloider medføre mindre væskeretensjon i perifert vev og dermed redusert risikoen for at det måtte utføres fasciotomier? Uansett er den akutte behandlingen av denne typen pasienter komplisert og krever et godt og bredt samarbeid på tvers av forskjellige spesialiteter.

Pasienten har gitt samtykke til at artikkelen blir publisert.

\section{Margaret Garnes (f. 1970)}

er spesialist i indremedisin og i blodsykdommer og er overlege.

Forfatter har fylt ut ICMJE-skjemaet og oppgir ingen interessekonflikter.

\section{Jens Bøen (f. 1956)}

er spesialist i anestesiologi og er overlege.

Forfatter har fylt ut ICMJE-skjemaet og oppgir ingen interessekonflikter.

\section{Litteratur}

1. Clarkson B, Thompson D, Horwith M et al. Cyclical edema and shock due to increased capillary permeability. Am J Med 1960; 29: 193-216.

2. Druey KM, Greipp PR. Narrative review: the systemic capillary leak syndrome. Ann Intern Med 2010 153: $90-8$.

3. Gousseff M, Arnaud L, Lambert $M$ et al. The systemic capillary leak syndrome: a case series of 28 patients from a European registry. Ann Intern Med 2011; 154: 464-71

4. Kapoor P, Greipp PT, Schaefer EW et al. Idiopathic systemic capillary leak syndrome (Clarkson's disease): the Mayo clinic experience. Mayo Clin Proc 2010; 85: 905-12

5. Xie Z, Ghosh CC, Patel R et al. Vascular endothelia hyperpermeability induces the clinical symptoms of Clarkson disease (the systemic capillary leak syndrome). Blood 2012; 119: 4321-32.

6. Tahirkheli NK, Greipp PR. Treatment of the systemic capillary leak syndrome with terbutaline and theophylline. A case series. Ann Intern Med 1999. 130: $905-9$

7. Lambert M, Launay D, Hachulla E et al. High-dose intravenous immunoglobulins dramatically reverse systemic capillary leak syndrome. Crit Care Med 2008; 36: 2184-7.

8. Rechner I, Brito-Babapulle F, Fielden J. Systemic capillary leak syndrome after granulocyte colonystimulating factor (G-CSF). Hematol J 2003; 4 : $54-6$

9. Yamamoto K, Mizuno M, Tsuji T et al. Capillary leak syndrome after interferon treatment for chronic hepatitis C. Arch Intern Med 2002; 162: 481-2.

10. Dahan L, Ressiot E, Cournede A et al. Anasarca, a complication of chemotherapy with gemcitabine in two patients with pancreatic cancer. Gastroenterol Clin Biol 2007; 31: 1143-5.

11. Kaplan MJ, Ellis CN, Bata-Csorgo Z et al. Systemic toxicity following administration of sirolimus (formerly rapamycin) for psoriasis: association of capillary leak syndrome with apoptosis of lesional lymphocytes. Arch Dermatol 1999; 135: 553-7.

Mottatt 9.8. 2013, første revisjon innsendt 26.12. 2013, godkjent 7.10. 2015. Redaktør: Sigurd Høye. 